\title{
Implementation of Rice, Corn, Soybean Intercropping Planting System on Acid Land Agroecosystem in Lampung Area
}

\author{
Slameto*, Meidaliyantisyah, and J. Barus \\ Lampung Assessment Institute of Agricultural Technology, \\ Jl. ZA Pagar Alam no. 1A, Rajabasa, Bandar Lampung 35145, Indonesia \\ *Corresponding author. Email: islameto@yahoo.co.id
}

\begin{abstract}
The acidic wetlands of 410,177 ha in Lampung are potentialfor food crops. The main characteristic of acid land is relatively low productivity for main food crops such as rice, corn, and soybeans. A study of agricultural technology innovations application with intercropping systems of rice-corn-soybean has been carried out in Tanggamus district, Lampung. The research was in a demonstration plot of 3.0 ha. It was comparing 3 types of planting systems using intercropping of upland rice - corn, upland rice - soybean and corn - soybean. The results showedan average yield of corn of $8,089 \mathrm{~kg} / \mathrm{ha}$ and soybean of $1,971 \mathrm{~kg} / \mathrm{ha}$ in the intercropping system of corn and soybeans with a 2-7 pattern (Turiman Jale 2-7), corn of 12,959 kg/ha and upland riceof $2,104 \mathrm{~kg} / \mathrm{ha}$ in the intercropping system of upland corn and rice with a 2-9 pattern (Turiman Jago 2-9) and upland riceof $3,175 \mathrm{~kg} / \mathrm{ha}$ and soybean of $2,516 \mathrm{~kg} / \mathrm{ha}$ in the intercropping system of upland rice and soybeans with a 9-5 pattern (Turiman Gole 9-5). In the future, the potential of the intercropping planting system will provide benefits of land use efficiency, harvesting of two types of commodities, added value to yield planting with the population of $150-200 \%$, minimizing crop failure, and sustainability of farming. However, it is very necessary to consider the efficient use of water, and the calculation of the planting schedule according to the proper planting calendar.
\end{abstract}

Keywords: intercropping, rice, corn, soybean, acid land, Lampung

\section{INTRODUCTION}

According to Mulyani et al. [1], the area of acid land in Indonesia reaches 148 million ha. Acid soil that is found in rice fields, derived from advanced weathered mineral materials and swamps that are mainly found in acid sulfate soils and organic soils. Widjaja-Adhi et al., [2] stated that in Indonesia, swamps cover an area of around 33.4-39.4 million ha, spreading predominantly in the islands of Sumatra, Kalimantan, Sulawesi and Papua. The area of acidic wetlands in Lampung is around 544,305 ha, most of them are potential for food crops (rice) covering an area of 410,177 ha $[3,4]$. The main characteristic of acid land is relatively low productivity for main food crops such as rice, corn, and soybeans. Increasing productivity requires balanced fertilization, both organic and inorganic fertilizers, and liming to increase soil $\mathrm{pH}$.

Rainfed rice fields are land for the cultivation of food crops which rely on rainwater. In Lampung, rainfed rice fields are categorized as sub-optimal because the soil is acidic, less fertile and rainfall dependable water resource. The area of rainfed rice fields in Lampung is estimated to be 121,049 ha $[5,6]$ or about $27 \%$ of
Lampung's total rice fields which is 445,173 ha [7]. The cropping index (CI) of the rainfed lowland is still low (1$1.5)$. Rice productivity in rain fed lowland which is in the range of 3-7 ton/ha [8], still has the potential to optimize land use to support increased rice yield.

On the other hand, water is a limiting factor for food crop yield, such as rice, corn and soybean. In order to increase productivity, the role of availability of water occupies a portion of $16 \%$, the use of superior seeds contributes $5 \%$, the application of technology contributes $4 \%$, and the interaction of these three factors contributes $75 \%$ [9]. Thus, the improvement of irrigation water infrastructure is important to increase yield [10,11]. Increasing productivity can also be done by managing the subsystem of soil, water and cropping patterns for land use over a certain period of times [12].

According to Andrianto and Indarto [13], low food (rice, corn, and soybeans) yield in Indonesia is due to poor farming methods and limited land areas. Intensification of productive agricultural land and extensification are commonly used to solve the problem [14]. In terms of intensification, intercropping system is an alternative solution to increase land productivity. Several 
intercropping studies show, among others, Pujiwati [15] and Susilo [16] that the productivity of rice and beans intercropping is higher than the monoculture cropping system. The intercropping of the two commodities has complementary effect. Intercropping of cassava with upland rice, corn, soybeans, beans is very potential and prospective [17]. Research by Dewi, Soelistyono and Suryanto [18] shows that the intercropping of upland rice with sweet corn tends to have higher yields than intercropping treatment with other crops.

For this reason, the purpose of this study was to analyze yield level of the intercropping system of ricecorn-soybean cropping on acid rainfed lowland areas in the Tanggamus district, Lampung Province.

\section{METHODOLOGY}

This study implemented an innovative intercropping system technology to increase rice, corn and soybean yield in rainfed fields specific to the Lampung region. The application of intercropping technology innovation was carried out by modifying the planting system suitable for Lampung region as previous research studies such as the study of the East Java AIAT [19] and Musyafak et. al. [20]. The location of the activity was in rainfed rice fields covering an area of 3.0 ha in Banjar Masin Village, Bulok District and Banjar Agung Udik Village, Pugung District, Tanggamus Regency, Lampung Province.

The study was conducted during the second planting season (MT-II) from May to September 2019. The study involved 11 cooperative farmers who have rainfed rice fields. The cropping system models implemented were: (1) corn + soybean intercropping system covering 2 rows of corn and 7 rows of soybean (Turiman Jale 2-7); (2) an intercropping system of corn + upland rice covering 2 rows of corn and 9 rows of upland rice crops (Turiman Jago 2-9); and (3) an intercropping system of upland rice + soybean includes 9 rows of upland rice and 5 rows of soybean (Turiman Gole 9-5). The innovation components that had been used were new improved varieties (NIV) for corn, soybeans and upland rice, bio-decomposers, the seed treatment, biological fertilizers, organic fertilizer/compost, chemical fertilizers, soil lime/dolomite, and liquid biosilica.

The corn varieties were Nasa-29 and local existing varieties (BS-18), upland rice varieties were Rindang-1 and Inpago-12, while soybean varieties included Anjasmoro, Devon, Dena and Local Tanggamus varieties. In the maintenance process, the innovations of agricultural technology that were used starting from planting, the fertilization process, controlling pests and diseases and so on, were aligned with the technical guidelines for intercropping cultivation (turiman) prepared by the IAARD while still considering the suitability of the specific location of the Lampung region.

The data observed included the growth and yield of the three plants and their implementation on land use. Data analysis was performed using descriptive statistics.

\section{RESULTS AND DISCUSSION}

The main component of the modified and harmonized intercropping plant innovation was based onthe intercropping study conducted by Agricultural Research and Development Agency, especially the East Java AIAT [19] and Musyafak et al., [21].

The results of this study were 3 (three) models of intercropping plant system innovation (turiman) as described in the research method. The application of these three intercropping innovations in the field was based on the preferences of the farmer cooperators involved the study. The farmer was free to adopt among 3 models of intercropping systems, whether Turiman Jale 2-7 or Turiman Jago 2-9 or Turiman Gole 9-5.The decision was discussed among the farmers themselves in their farmer groups on which model they wish to adopt. The choice of implementing the three innovations in the turiman system by farmers considered the irrigation conditions and local water availability conditions.

The results of the study on the application of agricultural technology innovation with an intercropping system of rice-corn-soybean in acid rainfed rice fields in the Tanggamus district, Lampung Province, showed in general the growth of rice, corn and soybean for vegetative and generative phases, were quite good. The results of the study are presented in the following description.

\subsection{Corn-Soybean Intercropping System (Turiman Jale 2-7)}

\subsubsection{Corn yield components}

In the intercropping system of corn and soybean (Turiman jale 2-7) planted in the Tanggamus area, the corn varieties that were planted were Nasa-29 (IAARD innovation) and BS-18 (the existing local varieties which were widely found in the Tanggamus study area). Meanwhile, the soybean varieties grown were Anjasmoro, Dena, Devon and local existing one. The results of observations on the growth and yield of corn in the 2-7 corn-soybean turiman planting system planted in Banjar Masin Village, Bulok District, Tanggamus Regency showed that the Nasa-29 corn in the vegetative growth phase was quite good, but in the next stage development, it experienced crop failure. Harvest failure was due to very extreme dry conditions during the generative phase of the plant which resulted in drought and had an impact on corn crops (Table 1).

Meanwhile, for the corn that was planted first in Banjar Agung Udik Village, Pugung District, Tanggamus Regency, had a good condition because it was planted earlier (BS-18 and Nasa-29) which were combined with local soybeans. Table 1 shows that Nasa-29 corn provided productivity of $6,798 \mathrm{~kg} / \mathrm{ha}$ at a moisture content of $17 \%$. BS-18 corn intercropped with local variety, Devon, Anjasmoro and Dena had yields of 4,301 kg/ha, 8,695 
$\mathrm{kg} / \mathrm{ha}, 9,589 \mathrm{~kg} / \mathrm{ha} 11,065 \mathrm{~kg} / \mathrm{ha}$, respectively. In order to avoid drought,calculating the right planting time and hastening planting when the land is ready for planting is highly recommended to catch up with the planting season and still get a supply of rainwater.

Table 1 Corn plant growth and yield in Turiman Jale 2-7 in Tangamus, Lampung, 2019

\begin{tabular}{|c|c|c|c|c|c|c|c|c|}
\hline No & $\begin{array}{l}\text { Intercropping } \\
\text { System }\end{array}$ & $\begin{array}{l}\text { Plant } \\
\text { height } \\
(\mathrm{cm})\end{array}$ & $\begin{array}{l}\text { Number } \\
\text { of leaves }\end{array}$ & $\begin{array}{l}\text { Corn } \\
\text { cob } \\
\text { weight } \\
(\mathrm{gr})\end{array}$ & $\begin{array}{l}\text { Number } \\
\text { of plants } \\
\text { per tile } \\
\left(6.25 \mathrm{~m}^{2}\right)\end{array}$ & $\begin{array}{l}\text { Number } \\
\text { of cobs } \\
\text { per tile } \\
\left(6.25 \mathrm{~m}^{2}\right)\end{array}$ & $\begin{array}{l}\text { Weight of } \\
\text { shelled } \\
\text { cornper } \\
\text { tile (gr) }\end{array}$ & $\begin{array}{c}\text { Yield } \\
(\mathrm{kg} / \mathrm{ha})\end{array}$ \\
\hline A. & $\begin{array}{l}\text { Corn (Nasa-29) } \\
\text { + Soybean: }\end{array}$ & & & & & & & \\
\hline 1. & Anjasmoro & 83,8 & 7,72 & $\mathrm{~F}$ & $\mathrm{~F}$ & $\mathrm{~F}$ & $\mathrm{~F}$ & $\mathrm{~F}$ \\
\hline 2. & Dena & 108,4 & 11,64 & $\mathrm{~F}$ & $\mathrm{~F}$ & $\mathrm{~F}$ & $\mathrm{~F}$ & $\mathrm{~F}$ \\
\hline 3. & Devon & $\mathrm{F}$ & $\mathrm{F}$ & $\mathrm{F}$ & $\mathrm{F}$ & $\mathrm{F}$ & $\mathrm{F}$ & $\mathrm{F}$ \\
\hline 4. & Lokal & 89,04 & 7,56 & 160,82 & 28,2 & 24,6 & 1.632 & 6.798 \\
\hline B. & $\begin{array}{l}\text { Corn }(\text { BS-18) + } \\
\text { Soybean: }\end{array}$ & & & & & & & \\
\hline 1. & Anjasmoro & 209,04 & 12,00 & 186,01 & 28,4 & 22 & 2.301 & 9.589 \\
\hline 2. & Dena & 199,12 & 12,32 & 180,60 & 25,2 & 23 & 2.656 & 11.065 \\
\hline 3. & Devon & 200,96 & 11,32 & 177,52 & 29,8 & 20,4 & 2.028 & 8.692 \\
\hline 4. & Lokal & 155,76 & 10,72 & 178,28 & 38,4 & 30,8 & 1.032 & 4.301 \\
\hline
\end{tabular}

\subsubsection{Soybean yield components}

Observation of the growth and yield of soybeans in the corn-soybean intercropping system (Turiman jale 2-7) showed that the yield of various soybean varieties was obtained. The soybean intercropping with corn plants Nasa-29 showed Anjasmoro variety $(2,321 \mathrm{~kg} / \mathrm{ha})$ gave the highest yield compared to Dena $(1,464 \mathrm{~kg} / \mathrm{ha})$, Devon
$(2,174 \mathrm{~kg} / \mathrm{ha})$, and local (706.1 kg/ha) varieties. Mean while, when intercropping with BS-18 corn, it showed that the Devon soybean variety gave the highest yield $(2,174$ $\mathrm{kg} / \mathrm{ha}$ ) compared to other soybean varieties, Anjasmoro $(2,143 \mathrm{~kg} / \mathrm{ha})$, Dena $(2,127 \mathrm{~kg} / \mathrm{ha})$, and local $(2,194 \mathrm{~kg})$. The complete results of the analysis of soybean plants are shown in Table 2.

Table 2 Soybean plant growth and yield in Turiman Jale 2-7 in Tangamus, Lampung, 2019

\begin{tabular}{|c|l|c|c|c|c|c|c|c|}
\hline No & \multicolumn{1}{|l|}{$\begin{array}{c}\text { Intercropping } \\
\text { System }\end{array}$} & $\begin{array}{c}\text { Plant } \\
\text { height } \\
(\mathrm{cm})\end{array}$ & $\begin{array}{c}\text { Number } \\
\text { of } \\
\text { branches }\end{array}$ & $\begin{array}{c}\text { Number } \\
\text { ofpods }\end{array}$ & $\begin{array}{c}\text { Plant } \\
\text { weight } \\
(\mathrm{gr})\end{array}$ & $\begin{array}{c}\text { Number } \\
\text { of plant } \\
\text { per tile } \\
\left(6.25 \mathrm{~m}^{2}\right)\end{array}$ & $\begin{array}{c}\text { Weight of } \\
\text { soybean } \\
\text { per tile } \\
(\mathrm{gr})\end{array}$ & $\begin{array}{c}\text { Yield } \\
(\mathrm{kg} / \mathrm{ha})\end{array}$ \\
\hline A. & $\begin{array}{l}\text { Corn (Nasa-29) } \\
\text { + Soybean: }\end{array}$ & & & & & & & \\
\hline 1. & Anjasmoro & 59,13 & 2,88 & 64,60 & 18,56 & $\underline{73,8}$ & 464,20 & 2.321 \\
\hline 2. & Dena & 58,01 & 3,68 & 37,88 & 14,52 & 87,8 & 292,76 & 1.464 \\
\hline 3. & Devon & 49,84 & 3,16 & 36,16 & 34,49 & 59,2 & 391,34 & 2.174 \\
\hline 4. & Lokal & 46,32 & 3,64 & 39,96 & 11,08 & 119 & 141,22 & 706,1 \\
\hline B. & $\begin{array}{l}\text { Corn (BS-18)+ } \\
\text { Soybean: }\end{array}$ & & & & & & & \\
\hline 1. & Anjasmoro & 52,36 & 3,52 & 72,84 & 17,63 & $\underline{71,54}$ & 450,00 & 2.143 \\
\hline 2. & Dena & 76,16 & 3,36 & 63,92 & 26,26 & 39,40 & 528,52 & 2.127 \\
\hline 3. & Devon & 43,06 & 3,44 & 56,64 & 18,09 & $\underline{72,43}$ & 478,74 & 2.279 \\
\hline 4. & Lokal & 60,42 & 3,08 & 64,68 & 21,88 & 66,40 & 438,78 & 2.194 \\
\hline
\end{tabular}

Source: field observation data, 2019. Moisture content of harvested soybean $12.29 \%$.

Description: A = Location is in Banjar Masin Village, Bulok District, Tanggamus Regency

$\mathrm{B}=$ Location in Banjar Agung Udik Village, Pugung District, Tanggamus Regency 
The intercropping system of corn and soybean with a 2-7 pattern (Turiman Jale 2-7) gave an average corn yield of $8,089 \mathrm{~kg} / \mathrm{ha}$ and an average soybean yield of 1,971 $\mathrm{kg} / \mathrm{ha}$. The results of the intercropping system for corn and soybeans are in line with studies conducted by Yuwariah et. al. [21] where the intercropping of hybrid corn and soybeans gave a corn yield of $6,350 \mathrm{~kg} / \mathrm{ha}$. Meanwhile, the Research Institute for Various Beans and Tubers, reported that the intercropping of corn and soybeans gave optimal results for corn grown by double rowing a population of 100,000 plants/ha. Between these double rows of corn planted 3 rows of soybeans with a population of 375,000 plants/ha, and Corn is planted 20 days after planting soybeans [22].

\subsection{Corn-upland rice Intercropping System (Turiman Jago 2-9)}

\subsubsection{Corn yield components}

The intercropping system of corn and upland rice (turimanjago 2-9) planted in Banjar Agung Udik Village, Pugung District and Banjar Masin District, Bulok District, Tanggamus Regency hadthe same corn varieties planted as in the corn-soybean intercropping system which were Nasa-29 (IAARD innovation) and BS-18 (local existing in the planting demonstration plot area of Tanggamus district). The upland rice varieties planted were Rindang-1 and Inpago-12. The growth and yield of existing local corn (BS-18) was very optimal in the demonstration plot in the Pugung District, Tanggamus Regency. However, the results of the yield of the corn varieties of Nasa-29 intercropped with Rindang-1 experienced crop failure due to the extreme dry conditions at that time due to the late corn planting time. So that it experienced a lack of water during the generative growth phase.

Table 3Corn plant growth and yield in Turiman Jago 2-9 in Tangamus, Lampung, 2019

\begin{tabular}{|r|l|c|c|c|c|c|c|c|}
\hline No & $\begin{array}{c}\text { Intercropping } \\
\text { System }\end{array}$ & $\begin{array}{c}\text { plant } \\
\text { height } \\
(\mathrm{cm})\end{array}$ & $\begin{array}{c}\text { Number } \\
\text { of leaves }\end{array}$ & $\begin{array}{c}\text { Corn } \\
\text { cob } \\
\text { weight } \\
(\mathrm{gr})\end{array}$ & $\begin{array}{c}\text { Number } \\
\text { of plants } \\
\text { per tile } \\
\left(6.25 \mathrm{~m}^{2}\right)\end{array}$ & $\begin{array}{c}\text { Number } \\
\text { of cobs } \\
\text { per tile } \\
\left(6.25 \mathrm{~m}^{2}\right)\end{array}$ & $\begin{array}{c}\text { Weight of } \\
\text { shelled } \\
\text { corn per } \\
\text { tile }(\mathrm{gr})\end{array}$ & $\begin{array}{c}\text { Yield } \\
(\mathrm{kg} / \mathrm{ha})\end{array}$ \\
\hline A. & $\begin{array}{l}\text { Corn (Nasa-29) } \\
+ \text { Upland Rice: }\end{array}$ & & & & & & & \\
\hline 1. & Rindang-1 & 100,4 & 9,16 & $\mathrm{~F}$ & $\mathrm{~F}$ & $\mathrm{~F}$ & $\mathrm{~F}$ & $\mathrm{~F}$ \\
\hline 2. & Inpago-12 & 85,4 & 13,8 & 105,82 & 24 & 23 & 2.433 & 10.138 \\
\hline B. & $\begin{array}{l}\text { Corn (BS-18) + } \\
\text { Upland Rice: }\end{array}$ & & & & & & \\
\hline 1. & Rindang-1 & 203,44 & 13,12 & 110,38 & 40 & 35 & $3.863,3$ & 19.316 \\
\hline 2. & Inpago-12 \\
Source: field observation data, 2019. Moisture content of harvested corn 19\% \\
Description: A = Location is in Banjar Masin Village, Bulok District, Tanggamus Regency \\
B = Location in Banjar Agung Udik Village, Pugung District, Tanggamus Regency \\
F = Failed to harvest due to drought.
\end{tabular}

Nasa-29 variety corn intercropped with Inpago- 12 upland rice still yielded $10,138 \mathrm{~kg} / \mathrm{ha}$ of wet shelled. The complete results of the conditions of intercropping corn with upland rice are shown in Table 3. Corn yield using the existing local type (BS-18) gave more yields $(19,316$ $\mathrm{kg} / \mathrm{ha}$ ) at an average of $19 \%$ moisture content when intercropped with upland rice of the Rindang-1 variety. The existing local corn intercropped with upland rice of Inpago-12 variety gave a yield of $22.385 \mathrm{~kg} / \mathrm{ha}$. In the future, it is recommended that corn cultivation in the Bulok Distrik, Tanggamus should consider proper planting time since availability of soil moisture is crucial to obtain better yield.

\subsubsection{Upland rice yield components}

Table 4 (the growth and yield of upland rice in the intercropping corn-upland rice (Turiman 2-9)) showsthat the upland rice tends to have low yield. This was because when the final phase of generative growth is replenished, it was at the end of the rainy season which rain frequency was reduced and water tends to be insufficient for upland rice.

The upland rice intercropped with Nasa-29 and local existing corn varieties (BS-18) showed the Inpago-12 upland rice and Rindang-1 upland rice varieties only produce around $1000-2000 \mathrm{~kg} / \mathrm{ha}$. Results of upland rice growth and yield are shown in Table 4. Inpago-12 intercropped with Nasa-29 corn plants provided a very suboptimal yield $(380 \mathrm{~kg} / \mathrm{ha})$ at a moisture content of $10.5 \%$. This is also due to drought, pests and diseases. Meanwhile, the upland rice variety Rindang-1 grown in Bulok District, Tanggamus Regency was failure, whereas in the Pugung district, Tanggamus, upland rice of the Rindang-1 variety intercropped with the existing corn plants in the local area (BS-18) gave higher yield $(2,104$ 
$\mathrm{kg} / \mathrm{ha})$ than that of Inpago-12 variety $(1,169 \mathrm{~kg} / \mathrm{ha})$ at water content $10.5 \%$.

The intercropping system of corn and upland rice with a 2-9 pattern (Turiman Jago 2-9) gave an average corn yield of $12,959 \mathrm{~kg} / \mathrm{ha}$ and the highest upland rice yield was $2,104 \mathrm{~kg} / \mathrm{ha}$ at a harvest water content of $10.5 \%$. The yields from the intercropping system of upland corn and rice still provided yield even though upland rice was tend to be low. The upland rice yield was different from the previous research of intercropping corn and rice. Research by Dewi, Soelistyono and Suryanto [18] showed that the intercropping of upland rice with sweet corn tended to have higher yields compared to intercropping with other crops.

Table 4 Upland rice plant growth and yield in Turiman Jago 2-9 in Tangamus, Lampung, 2019

\begin{tabular}{|c|l|c|c|c|c|c|c|c|}
\hline No & \multicolumn{1}{|l|}{$\begin{array}{c}\text { Intercropping } \\
\text { System }\end{array}$} & $\begin{array}{c}\text { plant } \\
\text { height } \\
(\mathrm{cm})\end{array}$ & $\begin{array}{c}\text { Number } \\
\text { of tillers }\end{array}$ & $\begin{array}{c}\text { branches } \\
\text { per } \\
\text { panicle }\end{array}$ & $\begin{array}{c}\text { Number } \\
\text { of } \\
\text { grainsper } \\
\text { panicle }\end{array}$ & $\begin{array}{c}\text { Weight } \\
\text { of grains } \\
\text { per } \\
\text { panicle }\end{array}$ & $\begin{array}{c}\text { Weight of } \\
\text { grains per } \\
\text { tile }(6.25 \\
\left.\mathrm{m}^{2}\right)\end{array}$ & $\begin{array}{c}\text { Yield } \\
(\mathrm{kg} / \mathrm{ha})\end{array}$ \\
\hline A. & $\begin{array}{l}\text { Corn (Nasa-29) } \\
\text { + Upland Rice: }\end{array}$ & & & & & & & \\
\hline 1. & Rindang-1 & 54,96 & 9,8 & $\mathrm{~F}$ & $\mathrm{~F}$ & $\mathrm{~F}$ & $\mathrm{~F}$ & $\mathrm{~F}$ \\
\hline 2. & Inpago-12 & 81,08 & 8,48 & 9 & 137,4 & 0,76 & 68,4 & 380 \\
\hline B. & $\begin{array}{l}\text { Corn (BS-18)+ } \\
\text { Upland Rice: }\end{array}$ & & & & & & & \\
\hline 1. & Rindang-1 & 122,84 & 13,72 & 10,2 & 122,6 & 2,08 & 420,8 & 2.104 \\
\hline 2. & Inpago-12 & 93,64 & 18,16 & 9,4 & 121,8 & 1,44 & 210,5 & 1.169 \\
\hline
\end{tabular}

Source: field observation data, 2019. Moisture content of harvested rice $10.5 \%$

Description: $\mathrm{A}=$ Location is in Banjar Masin Village, Bulok District, Tanggamus Regency $\mathrm{B}=$ Location in Banjar Agung Udik Village, Pugung District, Tanggamus Regency $\mathrm{F}=$ Failed to harvest due to drought..

\subsection{Upland rice-Soybean Intercropping System (Turiman Gole 2-7)}

\subsubsection{Upland rice yield components}

The upland rice and soybean intercropping system 9-5 (turiman gole 9-5) grown in the Tanggamus area, the upland rice varieties were Rindang-1 and Inpago-12 (IAARD innovation), while the soybean varieties were Anjasmoro, Devon, Dena and Local one. All types of varieties were planted in the two demonstration plots, which were rainfed rice fields in Banjar Agung Udik village, Pugung district and Banjar Masin village, Bulok district, Tanggamus. (Table 5).

The growth and yield of upland rice in the intercropping system of upland rice-soybean, indicated that upland rice growth and yield in the vegetative phase had shown good performances for the two study demonstration plots in the Tanggamus Regency area. The upland rice yield of the Rindang-1 variety intercropped with Anjasmoro soybeans gave the highest upland rice productivity of $3,685 \mathrm{~kg} / \mathrm{ha}$. Meanwhile, the upland rice yield of the Rindang-1 variety intercropped with Dena variety gave upland rice productivity of $3,450 \mathrm{~kg} / \mathrm{ha}$. The average water content of upland rice was $19.11 \%$. As for the upland rice Rindang-1 intercropped with Devon and local varieties, did not produce a goodyield This condition was due to natural disasters in the form of drought in the final generative phase of rice plant growth that caused the rice grains did not contained (empty).
Meanwhile, Inpago-12 upland rice, intercropped with Anjasmoro, gave upland rice productivity of 2,869 $\mathrm{kg} / \mathrm{ha}$. And the upland rice yield of the Inpago- 12 variety intercropped with the Dena variety gave productivity of a $1,696 \mathrm{~kg} / \mathrm{ha}$. These yields are far below the yields of upland rice in monoculture where yield ranges from 3-4 ton/ha of harvested dry grain. This result is related to a shortage of irrigation water. At the time of grain filling, there is not enough water due to a long dry condition. As for the Inpago-12 upland rice, intercropped with Devon variety and local varieties of soybens, the conditions are the same as the Rindang- 1 upland rice variety which fails to produce filled grain due to the drought during the final generative growth phase (Table 5)

\subsubsection{Soybean rice yield components}

The results of observations on the growth and yield of soybean in the intercropping system of upland ricesoybean, it was found that the growth and yield of soybean had shown a good result (Table 6). In several varieties of soybean intercropped with upland rice plants, both Rindang-1 and Inpago-12 varieties showed soybean yield ranged from 2-3 tons per hectare with harvest dry moisture content of around $12 \%$. Anjasmoro soybean varieties tended to provide the highest yield compared to soybean varieties of Dena, Devon and local.

Soybean intercropped with upland rice var Rindang-1 showed that Anjasmoro soybean gave the highest yield $(3,127 \mathrm{~kg} / \mathrm{ha})$ compared to Dena $(2,371$ 
$\mathrm{kg} / \mathrm{ha})$, Devon $(2,174 \mathrm{~kg} / \mathrm{ha})$, and Local $(2,702 \mathrm{~kg} / \mathrm{ha})$. Meanwhile, the soybean intercropped with the Inpago-12 upland rice, Anjasmoro soybean variety also provided the highest yield $(2,922 \mathrm{~kg} / \mathrm{ha})$ compared to other soybean varieties, Dena (2,303 kg/ha), Devon (2,575 kg/ha), and Local $(1,960 \mathrm{~kg} / \mathrm{ha})$. Complete results of growth conditions and soybean yield in several varieties with an intercropping system with upland rice plants are shown in Table 6.
The system of intercropping upland rice and soybeans with a 9-5 pattern (turiman gole 9-5) gave an average upland rice yield of $3,175 \mathrm{~kg} / \mathrm{ha}$ and soybean yield of $2,516 \mathrm{~kg} / \mathrm{ha}$. In line with these results, Susilo and Purwito [23] stated that the intercropping system of upland rice and soybean enriched with organic fertilizers had a very significant effect on yield parameters for both upland rice and soybean yields.

Table 5 Upland rice plant growth and yield in Turiman Gole 9-5 in Tangamus, Lampung, 2019

\begin{tabular}{|r|l|c|c|c|c|c|c|c|}
\hline No & \multicolumn{1}{|l|}{$\begin{array}{c}\text { Intercropping } \\
\text { System }\end{array}$} & $\begin{array}{c}\text { plant } \\
\text { height } \\
(\mathrm{cm})\end{array}$ & $\begin{array}{c}\text { Number of } \\
\text { tillers }\end{array}$ & $\begin{array}{c}\text { branches } \\
\text { per } \\
\text { panicle }\end{array}$ & $\begin{array}{c}\text { Number of } \\
\text { grains per } \\
\text { panicle }\end{array}$ & $\begin{array}{c}\text { Weight of } \\
\text { grains per } \\
\text { panicle }\end{array}$ & $\begin{array}{c}\text { Weight of } \\
\text { grains per tile } \\
\left(6.25 \mathrm{~m}^{2}\right)\end{array}$ & $\begin{array}{c}\text { Yield } \\
(\mathrm{kg} / \mathrm{ha})\end{array}$ \\
\hline A. & $\begin{array}{l}\text { Upland Rice } \\
\text { (Rindang-1)+ } \\
\text { Soybean: }\end{array}$ & & & & & & \\
\hline 1. & Anjasmoro & 88,53 & 13,33 & 15,2 & 167,12 & 3,028 & 663,3 & 3.685 \\
\hline 2. & Dena & 93,60 & 12,60 & 12,36 & 191,44 & 4,000 & 653,5 & 3.450 \\
\hline 3. & Devon & 47,53 & 10,33 & $\mathrm{~F}$ & $\mathrm{~F}$ & $\mathrm{~F}$ & $\mathrm{~F}$ & $\mathrm{~F}$ \\
\hline 4. & Lokal & 60,48 & 15,68 & $\mathrm{~F}$ & $\mathrm{~F}$ & $\mathrm{~F}$ & $\mathrm{~F}$ & $\mathrm{~F}$ \\
\hline B. & $\begin{array}{l}\text { Upland Rice } \\
\text { (Inpago12)+ }\end{array}$ & & & & & & & \\
\hline Soybean: & & & & & & & \\
\hline Anjasmoro & Dena & 108,04 & 15,44 & 12,76 & 191 & 3,008 & 487,8 & 9.589 \\
\hline 3. & Devon & 107,32 & 14,08 & 10,92 & 127,72 & 2,848 & 254,4 & 11.065 \\
\hline 4. & Lokal & 39,73 & 14,6 & $\mathrm{~F}$ & $\mathrm{~F}$ & $\mathrm{~F}$ & $\mathrm{~F}$ & 8.692 \\
\hline
\end{tabular}

Source: field observation data, 2019. Moisture content of harvested upland rice $19,11 \%$.

Description: $\mathrm{F}=$ Failed to harvest due to drought.

Table 6 Soybean plant growth and yield in Turiman Gole 9-5 in Tangamus, Lampung, 2019

\begin{tabular}{|c|l|c|c|c|c|c|c|c|}
\hline No & \multicolumn{1}{|l|}{$\begin{array}{c}\text { Intercropping } \\
\text { System }\end{array}$} & $\begin{array}{c}\text { Plant } \\
\text { height } \\
(\mathrm{cm})\end{array}$ & $\begin{array}{c}\text { Number } \\
\text { of } \\
\text { branches }\end{array}$ & $\begin{array}{c}\text { Number } \\
\text { of pods }\end{array}$ & $\begin{array}{c}\text { Plant } \\
\text { weight } \\
(\mathrm{gr})\end{array}$ & $\begin{array}{c}\text { Number of } \\
\text { plant per tile } \\
\left(6.25 \mathrm{~m}^{2}\right)\end{array}$ & $\begin{array}{c}\text { Weight of } \\
\text { soybean per } \\
\text { tile }(\mathrm{gr})\end{array}$ & $\begin{array}{c}\text { Yield } \\
(\mathrm{kg} / \\
\text { ha) }\end{array}$ \\
\hline A. & $\begin{array}{l}\text { Upland Rice } \\
\text { (Rindang-1) } \\
\text { Soybean: }\end{array}$ & & & & & & & \\
\hline 1. & Anjasmoro & 55,52 & 3,36 & 72,8 & 29,712 & 34,0 & 500,40 & 3.127 \\
\hline 2. & Dena & 80,36 & 1,56 & 41,6 & 18,284 & 51,4 & 407,32 & 2.371 \\
\hline 3. & Devon & 44,84 & 3,16 & 36,16 & 34,49 & 59,2 & 391,34 & 2.174 \\
\hline 4. & Lokal & 40,45 & 3,84 & 38,48 & 30,26 & 73,2 & 486,36 & 2.702 \\
\hline B. & $\begin{array}{l}\text { Upland Rice } \\
\text { (Inpago12) + }\end{array}$ & & & & & & \\
\\
Soybean: & & & & & & & \\
\hline 1. & Anjasmoro & 54,22 & 3,6 & 68,64 & 26,91 & 37,8 & 467,90 & 2.922 \\
\hline 2. & Dena & 76,60 & 2,12 & 43 & 23,72 & 50 & 414,50 & 2.303 \\
\hline 3. & Devon & 49,61 & 3,64 & 34,16 & 32,09 & 57,4 & 463,38 & 2.575 \\
\hline 4. & 42,99 & 3,28 & 34,44 & 25,58 & 72,2 & 352,86 & 1.960 \\
\hline
\end{tabular}




\section{CONCLUSIONS AND RECOMMENDATIONS}

1. Implementation of agricultural technology innovation with the application of intercropping systems for the three types of crops (rice, corn, and soybeans) in acid rainfed lowlands, showed good growth and crop yield. The highest cornyield was produced in the intercropping system between corn and upland rice. The highest soybean yield was produced in the intercropping system between upland rice and soybean, while the highest upland rice yield was also produced in the intercropping system between upland rice and soybean.

2. The intercropping system of corn and soybeans with a 2-7 pattern (Turiman Jale 2-7) gave an average corn yield of $8,089 \mathrm{~kg} / \mathrm{ha}$ and soybean yield of $1,971 \mathrm{~kg} / \mathrm{ha}$.

3 . The intercropping system of upland corn and rice with a 2-9 pattern (Turiman Jago 2-9) gave an average corn yield of $12,959 \mathrm{~kg} / \mathrm{ha}$ and upland rice yield of 2,104 $\mathrm{kg} / \mathrm{ha}$.

4. The system of intercropping upland rice and soybeans with a 9-5 pattern (Turiman Gole 9-5) gave an average upland rice yield of $3,175 \mathrm{~kg} / \mathrm{ha}$ and soybean yield of $2,516 \mathrm{~kg} / \mathrm{ha}$.

5. The application of intercropping innovation between two crops provided increased yield of rice, corn, and soybeans in the area managed by farmers where there is added value in yield from one type of commodity to two commodities so as to minimize crop failure.

6. Intercropping system technology innovation between two or more types of plants provides benefits and advantages using very limited land. It would save labor cost, hence yields of 2 (two) types of commodities. With the modified density between plants, it can yield to $150-200 \%$ of regular planting system. Therefore, there is added value in yield, an increase in the crop harvest index, and can minimize the occurrence of crop failure for one commodity, even the sustainability of farming can be preserved. So, this innovation needs to be disseminated to farmers and agricultural technology users.

7. The application of an intercropping system needs to consider the the availability of water during the season and appopriate planting calendar to adjust for water availability to succeed

\section{ACKNOWLEDGMENT}

Acknowledgements is conveyed to BPTP Lampung and IAARD for the allocation of research costs. High appreciation goes to Agung Lasmono, Sunaryo, Herna Suhartin, Sandi
Nugroho, and Yuli Setyo Rahayu for all assistance in carrying out field research activities.

\section{REFERENCES}

[1] A. Mulyani, Hikmatullah, and H. Subagyo, 'Characteristics and potential of dry land acid soil in Indonesia', Proceedings of the National Symposium on the Utilization of Acidic Soils', Center for Research and Development of Soil and Agro-climate, Bogor, pp. 1-32, 2004.

[2] I.P.G. Widjaja-Adhi, D.A. Suriadikarta, M.T. Sutriadi, I G.M. Subiksa, and I.W. Suastika, 'Indonesian Land Resources and Management', Center for Soil and Agro-climate Research, Bogor,pp. 127-164,2000

[3] Puslitbangtanak, 'Atlas of Indonesian exploration land resources' Scale 1: 1,000,000, Center for Research and Development of Soil and Agro-climate, Bogor, 2000.

[4] Puslitbangtanak, 'Directive atlas of Indonesian agricultural spatial planning', Scale 1: 1,000,000, Center for Research and Development of Soil and Agro-climate, Bogor, 2001.

[5] Central Bureau Statistics, 'Area of rainfed rice fields, in: Lampung Province in Figures', Lampung Province, 2013

[6] Central Bureau Statistics, 'Extent of non-irrigated rice fields in Lampung, in: Lampung Province in Figures', Lampung Province,2016.

[7] IAARD, 'Map of the agroecological zone of Lampung Province', Scale 1: 250,000, Ministry of Agriculture,2013.

[8] B. Hafif, 'Sub-optimal land performance and improvement of productivity through regional policies in Lampung', Proceeding of National Seminar on Agricultural Technology Innovation, 13 pages, 2013.

[9] S. Suzanna, and E. Hutapea, 'Irrigation in Indonesia,the role of society and research', LP3ES Indonesia, Jakarta, 1995.

[10] Haryono, 'The impact of irrigation network development on yield', distribution and income, 2010.

[11] T.B. Purwantini, RR.S. Rivai, and E. Suryani, 'Impact of irrigation development on farmer welfare', National Seminar Proceedings. Farmers and Agricultural Development, Center for SocioEconomic and Agricultural Policy, pp.78-192, 2012.

[12] N.A. Fuadi,'Study of paddy productivity with pipe irrigation systems in watershed management',Bogor Agricultural Institute, 2016.

[13] T.T. Andrianto, and N. Indarto, 'Cultivation and business analysis of soybean, green beans, long beans farming', Absolute Publisher, Yogyakarta, 2004.

[14] I.G.M. Subiksa,'Utilization of mycorrhiza for critical land management', Bogor Agricultural Institute, 2002. 
[15] H. Pujiwati, 'Study of cultivation system implementation and weed control method in intercropping pattern of mung beans (Vigna radiate (L.) Wilczek) and Rice (Oryza sativa L.). Thesis (unpublished). Bogor Agricultural Institute, Bogor, 2004.

[16] E. Susilo, 'Application of cultivation systems and weed control methods in soybean (Glycine max (L.) Merr.) And Rice (Oryza sativa L.) in intercropping patterns', Bogor Agricultural Institute, 2004.

[17] T. Sundari, 'Technical instructions, Introduction of superior varieties and cassava cultivation techniques, in: Agribusiness Training Materials for KMPH', Report No. 55.STE. Final, Research Institute for Nuts and Tubers, Malang, 2010.

[18] S. Dewi, R. Surya, R. Soelistyono, andA. Suryanto,'Thestudyof intercroppinguplandpaddy (Oryzasativa L.) withsweetcorn (Zea mays saccharatasturt L.)',Journal of Plant Yield, Volume 2, Number 2, pp. 137-144, 2014.

[19] East Java AIAT,'guidelines for pajaleinter cropping cultivation techniques (Draft), East Java AIAT,
Agricultural Research and Development Agency, Ministry of Agriculture, 2018.

[20] A. Musyafak, Sution, A.Subekti, S.Nurita, S.S.Wibowo, and D.Fardenan,'Intercropping of cornrice upland-Soybean (Jagole)', West Kalimantan AIAT, 2018.

[21] Yuwariah, Y., D. Ruswandi and A.W. Irwan,'Effect of corn hybrid-soybean inter cropping on growth and yield of corn hybrid in Arjasari Bandung', Cultivation Journal Vol. 16, no. 3, Pp. 514-521, 2017.

[22] Research Institute for Various Nuts and Tubers, Intercropping of Corn with Soybeans in Rice Fields. Technology Info. Research Institute for Various Nuts and Tubers, 2019. Uploaded April 6, 2019 10:00. Website:http://balitkabi.litbang.pertanian.go.id. Accessed 19/9/2020 at 10:23 a.m.

[23] E. Susilo, and Purwito,'Intercropped cultivation system with LEISA concept: agricultural waste as organic fertilizer', Agroqua Journal. Vol. 11, No.2, 2013. 